\title{
Genetic characterization of antimicrobial resistance in coagulase-negative staphylococci from bovine mastitis milk
}

\author{
Yvonne Frey, Joan Peña Rodriguez, Andreas Thomann, Sybille Schwendener, and Vincent Perreten ${ }^{1}$ \\ Institute of Veterinary Bacteriology, Vetsuisse Faculty, University of Bern, CH-3012 Bern, Switzerland
}

\begin{abstract}
Coagulase-negative staphylococci (CNS; $\mathrm{n}=417$ ) were isolated from bovine milk and identified by matrix-assisted laser desorption/ionization time-offlight mass spectrometry. Nineteen different species were identified, and Staphylococcus xylosus, Staphylococcus chromogenes, Staphylococcus haemolyticus, and Staphylococcus sciuri were the most prevalent species. Resistance to oxacillin ( $47.0 \%$ of the isolates), fusidic acid $(33.8 \%)$, tiamulin (31.9\%), penicillin (23.3\%), tetracycline (15.8\%), streptomycin (9.6\%), erythromycin $(7.0 \%)$, sulfonamides (5\%), trimethoprim (4.3\%), clindamycin (3.4\%), kanamycin (2.4\%), and gentamicin (2.4\%) was detected. Resistance to oxacillin was attributed to the mecA gene in $9.7 \%$ of the oxacillin-resistant isolates. The remaining oxacillin-resistant CNS did not contain the mec $C$ gene or mecA1 promoter mutations. The mecA gene was detected in Staphylococcus fleurettii, Staphylococcus epidermidis, Staph. haemolyticus, and Staph. xylosus. Resistance to tetracycline was attributed to the presence of $\operatorname{tet}(\mathrm{K})$ and $\operatorname{tet}(\mathrm{L})$, penicillin resistance to blaZ, streptomycin resistance to str and ant(6)-Ia, and erythromycin resistance to $\operatorname{erm}(\mathrm{C})$, erm(B), and msr. Resistance to tiamulin and fusidic acid could not be attributed to an acquired resistance gene. In total, $15.1 \%$ of the CNS isolates were multidrug resistant (i.e., resistant to 2 or more antimicrobials). The remaining CNS isolates were susceptible to antimicrobials commonly used in mastitis treatment. Methicillin-resistant CNS isolates were diverse, as determined by mecA gene sequence analysis, staphylococcal cassette chromosome mec typing, and pulsed-field gel electrophoresis. Arginine catabolic mobile element types 1 and 3 were detected in both methicillin-resistant and methicillin-susceptible Staph. epidermidis and were associated with sequence types ST59 and ST111. Because this study revealed the presence of multidrugresistant CNS in a heterogeneous CNS population, we
\end{abstract}

Received August 27, 2012.

Accepted November 11, 2012.

${ }^{1}$ Corresponding author: vincent.perreten@vetsuisse.unibe.ch recommend antibiogram analysis of CNS in persistent infections before treatment with antimicrobials.

Key words: methicillin-resistance, coagulase-negative staphylococci, genotyping, antibiotic resistance

\section{INTRODUCTION}

Coagulase-negative staphylococci are the microorganisms most commonly isolated from bovine milk in many countries, and they are an important cause of mastitis (Pyörälä and Taponen, 2009; Rajala-Schultz et al., 2009; Piessens et al., 2011; De Vliegher et al., 2012). The CNS are opportunistic pathogens that are usually diagnosed as a group without species identification. They cause subclinical IMI that result in an increase in SCC and reduced milk quality, leading to economic losses (Pyörälä and Taponen, 2009). Because simple subclinical CNS infections can be self-limiting, they are usually not treated with antibiotics. However, CNS often appear with other major pathogens such as Staphylococcus aureus, Streptococcus spp., or coliform bacteria. In these cases and in persistent CNS infections, the cows undergo antimicrobial treatment. Currently, $\beta$-lactam antimicrobials (including penicillin and cephalosporins), aminoglycosides (gentamicin and neomycin), and macrolides (spiramycin) are commonly used to treat mastitis in Switzerland (Büttner et al., 2011). Resistance to these antibiotics has been increasingly reported in CNS associated with bovine mastitis (Walther and Perreten, 2007; Sawant et al., 2009; Sampimon et al., 2011). The CNS may also harbor antimicrobial resistance elements and pathogenicity islands, such as the staphylococcal cassette chromosome (SCCmec) element (Wielders et al., 2001; Barbier et al., 2010; Tsubakishita et al., 2010) and the arginine catabolic mobile element (ACME; Diep et al., 2006, 2008; Miragaia et al., 2009) that can be transferred to Staph. aureus. Arginine catabolic mobile elements are genomic islands in Staph. epidermidis that are associated with host colonization, fitness, and pathogenicity. Mobility of ACME is associated with recombinase genes present on the SCCmec elements (Goering et al., 2007; Diep et al., 2008). The SCCmec elements contain the mec genes - mecA or mecC $\left(m e c A_{\mathrm{LGA} 251}\right)$-which 
encode alternative penicillin-binding proteins (PBP 2a) and confer resistance to all $\beta$-lactam antimicrobials (García-Álvarez et al., 2011; Ito et al., 2012). In Staph. sciuri, the mecA gene homolog mecA1 is a native gene that is not part of the mec gene complex (Couto et al., 1996, 2000; Wu et al., 1998, 2001; Tsubakishita et al., 2010). Most Staph. sciuri isolates are susceptible to $\beta$-lactam antimicrobials. However, alterations in the promoter regions of mecA1 upregulate mecA1 expression and confer methicillin resistance (Wu et al., 2001, 2005; Couto et al., 2003). Methicillin-resistant staphylococci are often also resistant to other classes of drugs such as aminoglycosides and macrolides (Woodford 2005). Nevertheless, little is known about the molecular mechanisms of antimicrobial resistance (Lüthje and Schwarz, 2006) or the genetic background of multidrugresistant CNS strains in bovine milk.

We identified different CNS species in milk from cows with clinical and subclinical bovine mastitis, characterized their antimicrobial resistance mechanisms, and determined whether specific methicillin-resistant and multidrug-resistant CNS clones are common in dairy cows.

\section{MATERIALS AND METHODS}

\section{Origin of Milk Samples}

Coagulase-negative staphylococci $(\mathrm{n}=417)$ were isolated from milk $(\mathrm{n}=370)$ obtained from cows diagnosed with clinical $(\mathrm{n}=115)$ and subclinical $(\mathrm{n}=255)$ mastitis and control samples $(\mathrm{n}=47)$ in Switzerland. Control samples were collected from cows that had suffered from mastitis previously and had been treated; the control milk samples contained $<150,000$ cells $/ \mathrm{mL}$. The 417 isolates came from 363 different cows and from 2 different mammary quarters of 7 cows. The 363 cows originated from 195 different farms $\left(\mathbf{n}_{\mathrm{f}}\right)$ in the cantons of Berne $\left(\mathrm{n}_{\mathrm{f}}=91\right)$, Jura $\left(\mathrm{n}_{\mathrm{f}}=56\right)$, Fribourg $\left(\mathrm{n}_{\mathrm{f}}=\right.$ $26)$, Vaud $\left(\mathrm{n}_{\mathrm{f}}=8\right)$, Lucerne $\left(\mathrm{n}_{\mathrm{f}}=5\right)$, Valais $\left(\mathrm{n}_{\mathrm{f}}=4\right)$, Solothurn $\left(\mathrm{n}_{\mathrm{f}}=3\right)$, Aargau $\left(\mathrm{n}_{\mathrm{f}}=1\right)$, and Thurgau $\left(\mathrm{n}_{\mathrm{f}}\right.$ $=1$ ). In 47 cases, 2 different CNS strains were found in the same milk sample.

\section{Isolation and Identification of CNS}

Milk samples were centrifuged at $590 \times g$ for $10 \mathrm{~min}$ at room temperature. The milk pellets were cultivated on tryptone soy agar containing $5 \%$ defibrinated sheep blood (Becton, Dickinson and Co., Franklin Lakes, $\mathrm{NJ}$ ) and incubated at $37^{\circ} \mathrm{C}$ for 18 to $24 \mathrm{~h}$. Staphylococci were selected based on colony morphology, grampositive staining of cocci, and catalase production and were subcultured on tryptone soy agar containing $5 \%$ defibrinated sheep blood.

The isolates were identified by matrix-assisted laser desorption/ionization time-of-flight mass spectrometry (MALDI-TOF MS) analysis using the ethanol-formic acid extraction method for better resolution (Microflex LT, Bruker Daltonics GmbH, Bremen, Germany; Application Note MT-80, Bruker Daltonics GmbH). Species identification was considered valid when the matching score with reference spectra of the MALDI Biotyper v3.0 database (Bruker Daltonics $\mathrm{GmbH}$ ) was $\geq 2$, according to the criteria proposed by the manufacturer. Isolates whose measured spectra had score $<2.0$ were further identified by DNA sequencing of the $16 \mathrm{~S}$ rDNA (Kuhnert et al., 1996). The CNS strains were stored at $-80^{\circ} \mathrm{C}$ in trypticase soy medium containing $30 \%$ glycerin (Becton, Dickinson and Co.).

\section{DNA Extraction and Amplification}

To obtain total DNA, cells were incubated in 100 $\mu \mathrm{L}$ of Tris-EDTA buffer containing $0.1 \mathrm{mg} / \mathrm{mL}$ lysostaphin for $15 \mathrm{~min}$ at $37^{\circ} \mathrm{C}$; then, $450 \mu \mathrm{L}$ of lysis buffer (0.1 $M$ Tris-HCl, pH 8.5, 0.05\% Tween 20, $0.24 \mathrm{mg} /$ $\mathrm{mL}$ proteinase $\mathrm{K}$ ) was added and incubated at $60^{\circ} \mathrm{C}$ for $45 \mathrm{~min}$. The DNA was then denatured at $95^{\circ} \mathrm{C}$ for 15 min. The PCR was performed with HOT FIREPol DNA Polymerase (Solis BioDyne, Tartu, Estonia) using the primers and conditions listed in Table 1.

\section{Antimicrobial Resistance Tests}

The CNS isolates were tested for antimicrobial susceptibility with the broth microdilution technique (Clinical and Laboratory Standards Institute, 2009) using Sensititre susceptibility plates (NLEUST plates; Trek Diagnostics Systems, East Grinstead, UK) that contained the following 19 antimicrobials: chloramphenicol, ciprofloxacin, clindamycin, dalfopristin-quinupristin, erythromycin, fusidic acid, gentamicin, kanamycin, linezolid, mupirocin, oxacillin, penicillin, rifampicin, streptomycin, sulfamethoxazole, tetracycline, tiamulin, trimethoprim, and vancomycin. The resistance breakpoints were those proposed for CNS in the guidelines of the European Committee on Antimicrobial Susceptibility Testing (EUCAST, www.eucast.org; Table 2), except for streptomycin and kanamycin, for which breakpoints came from the French Society for Microbiology (www. sfm-microbiologie.org). The production of $\beta$-lactamase was tested on nitrocefin dry slides (Becton, Dickinson and Co.) using colonies grown on Mueller Hinton agar for $18 \mathrm{~h}$ at $37^{\circ} \mathrm{C}$ with $0.05 \mu \mathrm{g} / \mathrm{mL}$ penicillin to induce $\beta$-lactamase production (Schnellmann et al., 2006). The 
Table 1. Primers and primer sequences used in the study

\begin{tabular}{|c|c|c|c|c|}
\hline \multirow{2}{*}{$\frac{\text { Target gene }}{\text { mecA, mecA1, mecA2 }}$} & \multicolumn{2}{|c|}{ Primer name $(\mathrm{F}=$ forward $\mathrm{R}=$ reverse $)$ and sequence } & \multirow{2}{*}{$\begin{array}{c}\begin{array}{c}\text { Size of PCR } \\
\text { fragment (bp) }\end{array} \\
525\end{array}$} & \multirow{2}{*}{$\frac{\begin{array}{c}\text { Annealing } \\
\text { emperature }\left({ }^{\circ} \mathrm{C}\right.\end{array}}{51}$} \\
\hline & $\begin{array}{l}\text { mecAuniv-F } \\
\text { mecAuniv-R }\end{array}$ & $\begin{array}{l}\text { 5'-AAAAGATAAATCTTGGGGTG } \\
\text { 5'-CCTTGTTTCATYTTGAGTTC }\end{array}$ & & \\
\hline mecA1 & $\begin{array}{l}\text { mecA1-sc-F } \\
\text { mecA1-sc-R }\end{array}$ & $\begin{array}{l}\text { 5'-ATTAATCATCGCCATCGTGA } \\
\text { 5'-TTTGTATCTTGATTCATATTTTGAACA }\end{array}$ & 663 & 52 \\
\hline mecA1 promoter & $\begin{array}{l}\text { mecAscK1-F } \\
\text { mecAsc-R }\end{array}$ & $\begin{array}{l}\text { 5'-CATATATATATTTATACGCTCATC } \\
\text { 5'-TTCAATGGCATCAATTGTTTC }\end{array}$ & 335 & 50 \\
\hline $\begin{array}{l}m e c A^{1} \\
\text { (full-length gene) }\end{array}$ & $\begin{array}{l}\text { mecA-F7 } \\
\text { mecA-R7 }\end{array}$ & $\begin{array}{l}\text { 5'-GATAACACCTGCTACAC } \\
\text { 5'-AAGGGAGAAGTAACAGC }\end{array}$ & 2,194 & 51 \\
\hline
\end{tabular}

${ }^{1}$ Primers annealing external to $m e c A$ for amplification and sequencing of the full-length gene.

antimicrobial resistance genes were detected by using a custom-made microarray (AMR+ve-2 array tubes, Alere Technologies GmbH, Jena, Germany; Perreten et al., 2005). The microarray results were analyzed using the IconoClust program (Alere Technologies $\mathrm{GmbH}$ ), and the data were interpreted visually.

\section{Characterization of the mec Genes and SCCmec Elements}

All isolates displaying a MIC for oxacillin above the resistance breakpoint ( $\mathrm{MIC}>0.25 \mu \mathrm{g} / \mathrm{mL}$ ), which sug- gests the presence of an alternative penicillin-binding protein (based on Clinical and Laboratory Standards Institute and EUCAST), were additionally tested by PCR for the mecA, mecA1, and mecC genes (GarcíaÁlvarez et al., 2011; Ito et al., 2012) using the primers listed in Table 1. The complete nucleotide sequences of the mecA genes were obtained by PCR amplification with the mecA-F7 and mecA-R7 primers (Table 1). Sequencing was performed on an ABI Prism 3100 genetic analyzer (Applied Biosystems, Foster City, CA). The SCC mec types were determined by the Kondo method (Kondo et al., 2007).

Table 2. Distribution of antimicrobial resistance phenotypes in CNS

\begin{tabular}{|c|c|c|c|c|c|c|c|c|c|}
\hline \multirow[b]{3}{*}{ Antimicrobial substance } & \multirow{3}{*}{$\begin{array}{l}\text { Breakpoint } \\
(\mu \mathrm{g} / \mathrm{mL})\end{array}$} & \multicolumn{8}{|c|}{ Resistance phenotype } \\
\hline & & \multicolumn{2}{|c|}{$\begin{array}{c}\text { Total } \\
\left(\mathrm{n}_{\text {total }}=417\right)\end{array}$} & \multicolumn{2}{|c|}{$\begin{array}{l}\text { Clinical mastitis } \\
\left(\mathrm{n}_{\text {total }}=115\right)\end{array}$} & \multicolumn{2}{|c|}{$\begin{array}{c}\text { Subclinical } \\
\text { mastitis } \\
\left(\mathrm{n}_{\text {total }}=255\right)\end{array}$} & \multicolumn{2}{|c|}{$\begin{array}{c}\text { Control milk } \\
\left(\mathrm{n}_{\text {total }}=47\right)\end{array}$} \\
\hline & & No. & $\%$ & No. & $\%$ & No. & $\%$ & No. & $\%$ \\
\hline Oxacillin & $\mathrm{R}>0.25$ & 196 & 47.0 & $65^{\mathrm{a}}$ & 56.5 & $112^{\mathrm{a}}$ & 43.9 & 19 & 40.4 \\
\hline Penicillin & $\mathrm{R}>0.125$ & 97 & 23.3 & 26 & 22.6 & 63 & 24.7 & 8 & 17.0 \\
\hline Tetracycline & $\mathrm{R}>2.0$ & 66 & 15.8 & 18 & 15.7 & 37 & 14.5 & 11 & 23.4 \\
\hline Streptomycin & $\mathrm{R}>16$ & 40 & 9.6 & 9 & 7.8 & 29 & 11.4 & 2 & 4.3 \\
\hline Erythromycin & $\mathrm{R}>2.0$ & 29 & 7.0 & 7 & 6.1 & 18 & 7.1 & 4 & 8.5 \\
\hline Sulfamethoxazole & $\mathrm{R}>128$ & 21 & 5.0 & $13^{\mathrm{b}}$ & 11.3 & 8 & 3.1 & $0^{\mathrm{b}}$ & 0.0 \\
\hline Trimethoprim & $\mathrm{R}>4.0$ & 18 & 4.3 & 6 & 5.2 & 11 & 4.3 & 1 & 2.1 \\
\hline Clindamycin & $\mathrm{R}>0.5$ & 14 & 3.4 & 3 & 2.6 & 10 & 3.9 & 1 & 2.1 \\
\hline Ciprofloxacin & $\mathrm{R}>1.0$ & 0 & 0.0 & 0 & 0.0 & 0 & 0.0 & 0 & 0.0 \\
\hline Mupirocin & $\mathrm{R}>256$ & 0 & 0.0 & 0 & 0.0 & 0 & 0.0 & 0 & 0.0 \\
\hline
\end{tabular}




\section{Analysis of the mecA1 Promoter Region in Staph. sciuri}

Staphylococcus sciuri isolates carrying a mecA1 homo$\log (\mathrm{n}=37)$ were analyzed for a point mutation ( $\mathrm{Wu}$ et al., 2001) in the promoter region by restriction analysis of PCR products amplified with primers mecAscK1F and mecAsc-R (Table 1). The 335-bp PCR product was tested for PsiI cleavage using the manufacturer's suggested conditions (New England BioLabs, Beverly, MA); Psi recognizes the mutated promoter sequence TATAAT but not the wild-type sequence TATATT.

\section{Genotyping of Methicillin-Resistant CNS}

Methicillin-resistant, mecA-positive CNS isolates and multidrug-resistant, mecA-negative Staph. epidermidis isolates were genotyped by pulsed-field gel electrophoresis (PFGE). Analysis of SmaI-digested chromosomal DNA was performed as described previously (Schnellmann et al., 2006). Digested DNA was separated by gel electrophoresis in a contour-clamped homogeneous electric field DRIII device (Bio-Rad Laboratories Inc., Richmond, CA) with a ramped pulse time of 5 to $40 \mathrm{~s}$ at $6 \mathrm{~V} / \mathrm{cm}$ for $21 \mathrm{~h}$ at $12^{\circ} \mathrm{C}$. The lambda ladder $\mathrm{PFG}$ marker (New England BioLabs) was used as a size reference. The digital PFGE pattern images were analyzed with the BioNumerics software (Applied Maths, Kortrijk, Belgium), and the PFGE profiles were defined by the DNA banding patterns and criteria of Tenover et al. (1995).

\section{Multilocus Sequence Typing}

All Staph. epidermidis isolates $(\mathrm{n}=15)$ were examined by multilocus sequence typing (MLST), which is based on the sequencing of internal fragments of 7 housekeeping genes (Thomas et al., 2007). Allele and sequence type (ST) numbers were assigned according to the Staph. epidermidis MLST database (http://sepidermidis.mlst.net/).

\section{Detection of ica and ACME}

The Staph. epidermidis isolates $(\mathrm{n}=15)$ were tested by PCR for the biofilm operon ica (Gu et al., 2005) and ACME. The presence and type of ACME was determined using the primer pairs AIPS.27 and AIPS.28 for $\operatorname{arc} A$ and AIPS.45 and AIPS.46 for opp3 gene clusters (Diep et al., 2008).

\section{Statistical Analysis}

Antimicrobial resistance phenotypes (Table 2) were compared using the Fisher exact test. This test is useful when the sample size is small (zero in some cells), and the test evaluates the hypothesis that the 2 column percentages in a $2 \times 2$ table are equal. Statistical analysis was performed with the statistical software NCSS 2007 (www.ncss.com). The overall level of statistical significance was set to $P<0.05$.

\section{RESULTS}

\section{Prevalence and Identification of CNS}

In total, $97.8 \%$ of the CNS isolates $(n=408)$ were clearly identified at the species level by MALDI-TOF MS analysis. The most frequent CNS species were Staph. xylosus, Staph. chromogenes, Staph. sciuri, and Staph. haemolyticus (Table 3). The remaining $2.2 \%$ were identified by $16 \mathrm{~S}$ rDNA analysis as Staph. chromogenes $(\mathrm{n}=1)$, Staph. saprophyticus $(\mathrm{n}=1)$, or novel Staphylococcus species ( $\mathrm{n}=7$; Table 3). Neither clinical nor subclinical mastitis could be correlated with the presence of individual bacterial species. Similar species were identified in control milk samples with low SCC. Of the 417 CNS, 268 isolates were the only species present in the milk from which they originated, and 149 isolates were present together with at least one other species. Staphylococcus xylosus $(\mathrm{n}=92)$, Staph. chromogenes $(\mathrm{n}=56)$, Staph. haemolyticus $(\mathrm{n}=22)$, and Staph. sciuri $(\mathrm{n}=21)$ were the predominant species among the 268 isolates that had only a single CNS species present (Table 4). Among the mixed cultures, $18 \mathrm{CNS}$ isolates were co-purified with Staph. aureus (12.1\%), 83 isolates were present with Streptococcus spp. (55.7\%), and 48 isolates $(32.2 \%)$ were coincident in milk with at least one other bacterium (e.g., Trueperella pyogenes, Escherichia coli, Corynebacterium bovis, or a mix of more than 3 different bacteria; Table 4). In the milk samples, none of the CNS was found more frequently as a single agent than together with other bacteria, with the exception of Staph. chromogenes, which was not often found together with Staph. aureus or streptococci (Table 4).

\section{Analysis of Antimicrobial Resistance Phenotypes and Genotypes}

Oxacillin resistance, which is the indicator of mec gene-mediated methicillin resistance, was the most frequent resistance phenotype ( $47.0 \%$ of isolates), followed by resistance to fusidic acid $(34.1 \%)$, tiamulin $(31.9 \%)$, penicillin $(23.3 \%)$, tetracycline $(15.8 \%)$, streptomycin (9.6\%), and erythromycin (7.0\%; Table 2). Resistance to 2 or more antibiotics was observed in $15.1 \%$ of the CNS isolates. Multidrug-resistant isolates were found in milk from clinical $(\mathrm{n}=21)$ and subclinical $(\mathrm{n}=34)$ 
Table 3. Prevalence of CNS and distribution of different CNS strains in clinical and subclinical mastitis milk and control milk

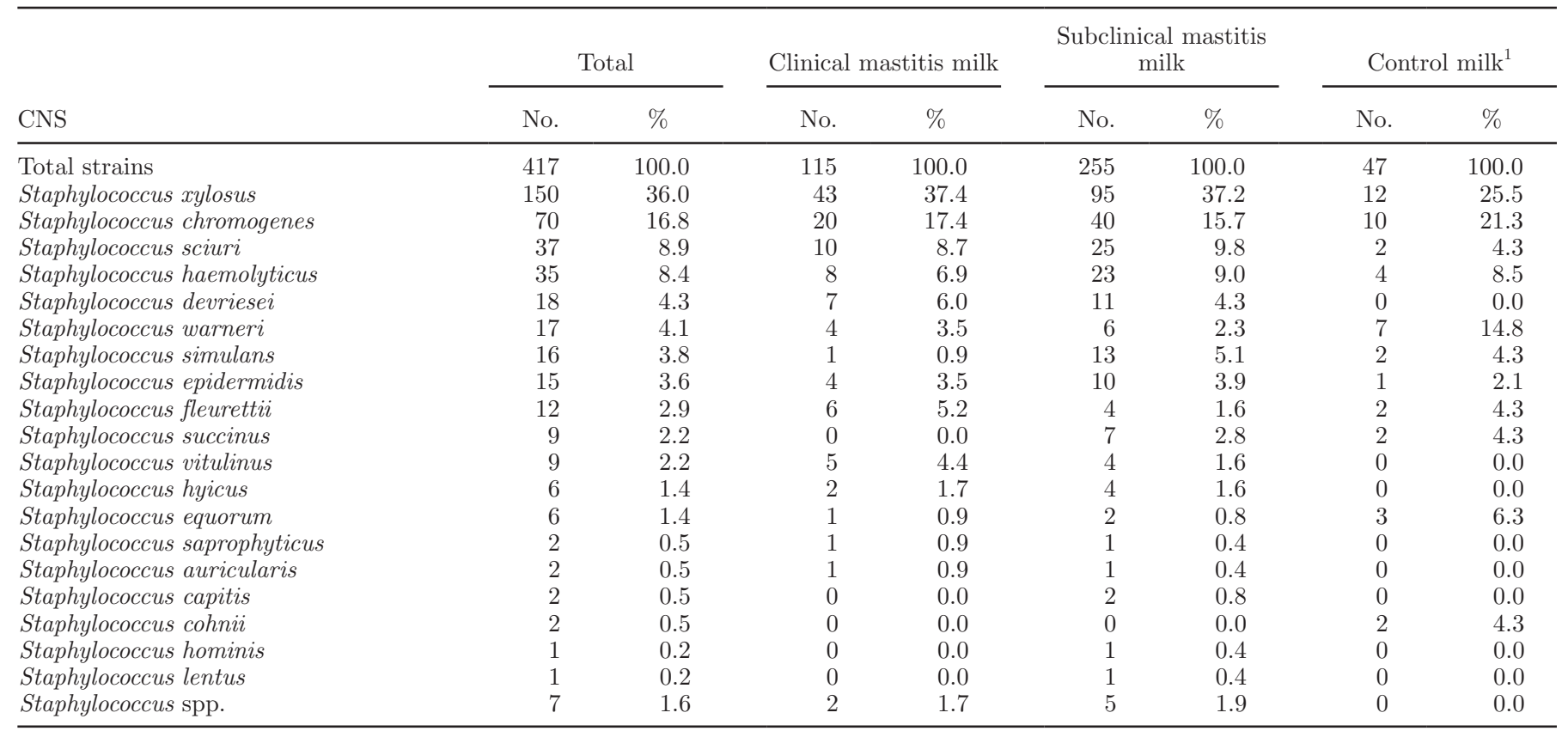

${ }^{1}$ Milk taken from cows after mastitis treatment.

mastitis cases and in control milk $(\mathrm{n}=8)$. Oxacillin isolates $(43.9 \%)$, whereas sulfamethoxazole resistance resistance was significantly more frequent in clinical was significantly more frequent in clinical mastitis mastitis isolates $(56.5 \%)$ than in subclinical mastitis isolates (11.3\%) than in control milk. No significant

Table 4. Distribution of CNS as single agent and associated with other pathogens in the milk samples

\begin{tabular}{|c|c|c|c|c|c|c|c|c|c|}
\hline \multirow[b]{3}{*}{ CNS } & \multicolumn{9}{|c|}{ Proportion of CNS $(\mathrm{n}=417)$} \\
\hline & \multirow{2}{*}{$\begin{array}{c}\begin{array}{c}\text { Total } \\
(\mathrm{n}=417)\end{array} \\
\text { No. }\end{array}$} & \multicolumn{2}{|c|}{$\begin{array}{l}\text { Occurring as a } \\
\text { single agent } \\
(\mathrm{n}=268)\end{array}$} & \multicolumn{2}{|c|}{$\begin{array}{c}\text { With Staph. } \\
\text { aureus }(\mathrm{n}=18)\end{array}$} & \multicolumn{2}{|c|}{$\begin{array}{c}\text { With } \\
\text { Streptococcus } \text { spp. } \\
(\mathrm{n}=83)\end{array}$} & \multicolumn{2}{|c|}{$\begin{array}{l}\text { With other } \\
\text { bacteria }^{1} \\
(\mathrm{n}=48)\end{array}$} \\
\hline & & No. & $\%$ & No. & $\%$ & No. & $\%$ & No. & $\%$ \\
\hline Staphylococcus chromogenes & 70 & 56 & 20.9 & 1 & 5.6 & 5 & 6.0 & 8 & 16.7 \\
\hline Staphylococcus sciuri & 37 & 21 & 7.8 & 1 & 5.6 & 10 & 12.0 & 5 & 10.4 \\
\hline Staphylococcus haemolyticus & 35 & 22 & 8.2 & 0 & 0.0 & 9 & 10.8 & 4 & 8.3 \\
\hline Staphylococcus devriesei & 18 & 13 & 4.9 & 0 & 0.0 & 3 & 3.6 & 2 & 4.2 \\
\hline Staphylococcus warneri & 17 & 11 & 4.1 & 1 & 5.6 & 3 & 3.6 & 2 & 4.2 \\
\hline Staphylococcus simulans & 16 & 14 & 5.2 & 0 & 0.0 & 2 & 2.4 & 0 & 0.0 \\
\hline Staphylococcus epidermidis & 15 & 10 & 3.7 & 2 & 11.1 & 2 & 2.4 & 1 & 2.1 \\
\hline Staphylococcus saprophyticus & 2 & 0 & 0.0 & 0 & 0.0 & 2 & 2.4 & 0 & 0.0 \\
\hline Staphylococcus auricularis & 2 & 1 & 0.4 & 0 & 0.0 & 1 & 1.2 & 0 & 0.0 \\
\hline Staphylococcus capitis & 2 & 2 & 0.7 & 0 & 0.0 & 0 & 0.0 & 0 & 0.0 \\
\hline Staphylococcus cohnii & 2 & 2 & 0.7 & 0 & 0.0 & 0 & 0.0 & 0 & 0.0 \\
\hline Staphylococcus hominis & 1 & 0 & 0.0 & 0 & 0.0 & 1 & 1.2 & 0 & 0.0 \\
\hline Staphylococcus lentus & 1 & 1 & 0.4 & 0 & 0.0 & 0 & 0.0 & 0 & 0.0 \\
\hline Staphylococcus spp. & 7 & 5 & 1.9 & 0 & 0.0 & 1 & 1.2 & 1 & 2.1 \\
\hline
\end{tabular}

${ }^{1}$ Indicates at least one species other than Staphylococcus aureus and Streptococcus spp. (e.g., Trueperella pyogenes, Escherichia coli, Corynebacterium bovis) or a mix of more than 3 different bacteria. 
difference in resistance between isolates was observed for the other antimicrobials tested (Table 2).

Oxacillin resistance was attributed to the mecA gene present in $9.7 \%(\mathrm{n}=19)$ of the oxacillin-resistant isolates $(\mathrm{n}=196)$. The mecA gene was detected in Staph. fleurettii (11/12), Staph. epidermidis (6/15), Staph. haemolyticus (1/37), and Staph. xylosus (1/155) isolates. The mecA or mec $C$ gene was not detected in the other 177 oxacillin-resistant isolates $(90.3 \%$; Table 5$)$. These isolates exhibited an oxacillin MIC of 0.5 or $1.0 \mu \mathrm{g} / \mathrm{mL}$, which is just above the clinical resistance breakpoint. Twenty of these 177 oxacillin-resistant mecA- and $m e c C$-negative isolates contained a bla $Z$ gene expressing a $\beta$-lactamase. The remaining isolates were also negative for blaZ (Table 5). Among them, all Staph. sciuri isolates $(\mathrm{n}=37)$ contained the mecA1 gene, and exhibited low-level resistance to oxacillin (MIC between 0.5 and $1.0 \mu \mathrm{g} / \mathrm{mL}$ ). The low oxacillin resistance was due to the absence of the $\mathrm{T} \rightarrow \mathrm{A}$ mutation in the -10 promoter sequence (Wu et al., 2001), as demonstrated by $P s i$ I restriction analysis.

Resistance to other antimicrobials correlated with the presence of the associated resistance genes (Table $5)$ : the $\beta$-lactamase gene blaZ; the tetracycline efflux genes tet $(\mathrm{L})$ and tet $(\mathrm{K})$; the streptomycin adenyltransferase and nucleotidyltransferase genes ant(6)-Ia and $s t r$; the chloramphenicol acetyltransferase genes cat $_{p C 221}$ and cat $_{p \text { C223; }}$ the gentamicin acetyltransferase gene aac $\left(6^{\prime}\right)-I e$; the kanamycin-neomycin phosphotransferase genes $a p h\left(2^{\prime}\right)-I a$ and $a p h\left(3^{\prime}\right)-I I I$; the macrolide and lincosamide $23 \mathrm{~S}$ rRNA methylase genes $\operatorname{erm}(\mathrm{B})$ and $\operatorname{erm}(\mathrm{C})$; the macrolide efflux gene $m s r$; the lincosamide nucleotidyltransferase gene $\ln u(\mathrm{~A})$; and the trimethoprim-resistant dihydrofolate reductase genes $d f r(\mathrm{~A}), d f r(\mathrm{D}), d f r(\mathrm{G})$, and $d f r(\mathrm{~K})$. In a few strains, resistance to erythromycin, clindamycin, streptomycin, gentamicin, chloramphenicol, and trimethoprim could not be explained by the presence of any of the tested genes, suggesting new antimicrobial resistance mechanisms in CNS (Table 5).

Resistance to fusidic acid was not due to the known fusidic acid resistance genes fus(B), and fus(C), suggesting the appearance of new resistance genes or mutations in the elongation factor G fus(A) (Farrell et al., 2011). Similarly, no known tiamulin resistance genes (vga or $l s a$ ) were detected in the tiamulin-resistant strains. Resistance to sulfonamides was not further characterized.

Multiple combinations of these genes were found in $4.8 \%$ of the CNS isolates. The most frequent resistance genes detected in combination were those conferring resistance to oxacillin, tetracycline, penicillin, streptomycin, gentamicin, kanamycin, erythromycin, and clindamycin (Table 6). The presence of several genes in one isolate was linked to the presence of mecA in Staph. epidermidis $(\mathrm{n}=6)$, Staph. sciuri $(\mathrm{n}=3)$, Staph. haemolyticus $(\mathrm{n}=1)$, and Staph. fleurettii $(\mathrm{n}=1)$. The other mecA positive isolates [Staph. fleurettii $(\mathrm{n}=10)$ and Staph. xylosus $(\mathrm{n}=1)$ ] contained only the mecA gene. The CNS isolates lacking mecA, but containing several other resistance genes were classified as Staph. chromogenes $(\mathrm{n}=3)$, Staph. epidermidis $(\mathrm{n}=3)$, Staph. haemolyticus $(\mathrm{n}=1)$, and Staph. warneri $(\mathrm{n}=2$; Table 6). All CNS isolates containing several resistance genes were found in milk samples from cows presenting with subclinical or clinical mastitis (Table 6). Although one Staph. xylosus isolate contained a mecA gene, multidrug resistance was never observed in Staph. xylosus, the most frequently detected CNS in our study.

\section{Genotyping of Methicillin-Resistant CNS}

The CNS strains containing the mecA gene $(\mathrm{n}=19)$ were further analyzed for mecA sequences, clonality, and SCCmec and ACME types. Two different mecA genes with slight sequence differences were detected in Staph. epidermidis isolates (Figure 1). Four mecA genes that slightly differed from each other were found in Staph. fleurettii (Figure 1). The mecA genes detected in Staph. haemolyticus and Staph. xylosus also differed slightly from each other and from those in Staph. epidermidis and Staph. fleurettii (Figure 1).

Analysis of methicillin-resistant Staph. epidermidis (n $=6)$ and Staph. fleurettii $(\mathrm{n}=11)$ by PFGE showed that strains of the same species were not clonally related, except for 4 Staph. fleurettii from 4 different farms that showed 2 similar PFGE patterns (Figure 1). Methicillin-resistant Staph. epidermidis belonged to ST59 (n = 2), ST55, ST89, and the new strains ST452 and ST454, whereas Staph. epidermidis strains lacking the mecA gene (methicillin-sensitive Staph. epidermidis, MSSE) and displaying a multidrug-resistance profile belonged to ST111 ( $=4)$, ST184 ( $=1)$, ST293 (n $=1)$, and to the new strain ST453 $(\mathrm{n}=1)$; MSSE also showed a different PFGE profile (data not shown).

Several different SCCmec elements were detected among the methicillin-resistant CNS isolates (Figure 1). Staphylococcus epidermidis strains contained SCCmec IV $(\mathrm{n}=4)$, SCCmec V $(\mathrm{n}=1)$, and one nontypeable SCCmec related to types IV and VI. Staphylococcus haemolyticus $(\mathrm{n}=1)$ and Staph. xylosus $(\mathrm{n}=1)$ both contained a nontypeable SCCmec. The mecA gene of Staph. fleurettii strains $(\mathrm{n}=11)$ were associated with the class A mec gene complex and could not be assigned to a known SCCmec element (Figure 1). Two methicillin-resistant Staph. epidermidis strains, ST59SCCmec IV and ST454-SCCmec V, contained a type 2 and type 3 ACME, respectively; ACME type 1 was 
Table 5. Distribution of antimicrobial resistance and antimicrobial resistance genes in CNS from bovine milk

\begin{tabular}{|c|c|c|c|c|c|}
\hline \multirow{2}{*}{$\begin{array}{l}\text { Antimicrobial } \\
\text { substance }\end{array}$} & \multirow{2}{*}{$\begin{array}{l}\text { Phenotypic } \\
\text { resistance }(\%)\end{array}$} & \multirow[b]{2}{*}{ Resistance genes $^{1}$} & \multicolumn{2}{|c|}{$\begin{array}{l}\text { Resistance genes } \\
\text { in resistant isolates }\end{array}$} & \multirow[b]{2}{*}{ Species (no.) } \\
\hline & & & No. & $\%$ & \\
\hline \multirow[t]{4}{*}{ Oxacillin $^{2}$} & \multirow[t]{4}{*}{47.0} & mecA & 19 & 9.7 & Staph. fleurettii (11), Staph. epidermidis (6), Staph. haemolyticus (1), Staph. xylosus (1) \\
\hline & & mecA1 & 37 & 18.9 & Staph. sciuri (37) \\
\hline & & No mecA/A1/C; blaZ & 20 & 10.2 & $\begin{array}{l}\text { Staph. chromogenes (9), Staph. xylosus (5), Staph. cohnii (2), Staph. saprophyticus (2), } \\
\text { Staph. warneri (2) }\end{array}$ \\
\hline & & No $m e c A / A 1 / C ;$ no blaZ & 120 & 61.2 & $\begin{array}{l}\text { Staph. xylosus (97), Staph. vitulinus (8), Staph. succinus (5), Staph. chromogenes (2), } \\
\text { Staph. devriesei (1), Staph. equorum (1), Staph. hyicus (1), Staph. lentus (1), Staph. } \\
\text { simulans (1), Staph. warneri (1), Staphylococcus spp. (2) }\end{array}$ \\
\hline \multirow[t]{3}{*}{ Penicillin ${ }^{3}$} & \multirow[t]{3}{*}{23.3} & blaZ & 88 & 90.7 & $\begin{array}{l}\text { Staph. chromogenes (37), Staph. devriesei (11), Staph. haemolyticus (11), Staph. xylosus } \\
\text { (9), Staph. epidermidis (9), Staph. warneri (3), Staph. cohnii (2), Staph. saprophyticus } \\
\text { (2), Staph. auricularis (1), Staph. capitis (1), Staph. fleurettii (1), Staph. hominis (1) }\end{array}$ \\
\hline & & No $\beta$-lactamase ${ }^{4}$ & 8 & 8.3 & Staph. fleurettii (8) \\
\hline & & Unknown & 1 & 1.0 & Staph. xylosus (1) \\
\hline \multirow[t]{2}{*}{ Tetracycline } & \multirow[t]{2}{*}{15.8} & $\operatorname{tet}(\mathrm{K})$ & 62 & 95.4 & $\begin{array}{l}\text { Staph. xylosus (33), Staph. warneri (7), Staph. epidermidis (6), Staph. sciuri (4), Staph. } \\
\text { chromogenes (3), Staph. simulans (3), Staph. fleurettii (2), Staph. vitulinus (2), Staph. } \\
\text { haemolyticus (1), Staphylococcus sp. (1) }\end{array}$ \\
\hline & & $\operatorname{tet}(\mathrm{L})$ & 3 & 4.6 & Staph. chromogenes (3) \\
\hline \multirow[t]{3}{*}{ Streptomycin } & \multirow[t]{3}{*}{9.6} & str & 36 & 90.0 & $\begin{array}{l}\text { Staph. chromogenes (12), Staph. epidermidis (7), Staph. sciuri (5), Staph. haemolyticus } \\
\text { (4), Staph. devriesei (3), Staph. warneri (2), Staph. simulans (1), Staph. vitulinus (1), } \\
\text { Staph. fleurettii (1) }\end{array}$ \\
\hline & & $\operatorname{ant}(6)-I a$ & 3 & 7.5 & Staph. epidermidis (2), Staph. haemolyticus (1) \\
\hline & & Unknown & 1 & 2.5 & Staph. haemolyticus (1) \\
\hline \multirow[t]{4}{*}{ Erythromycin } & \multirow[t]{4}{*}{7.0} & erm(B) & 2 & 7.4 & Staph. chromogenes (1), S fleurettii (1) \\
\hline & & $\operatorname{erm}(\mathrm{C})$ & 11 & 40.8 & Staph. epidermidis (6), Staph. haemolyticus (4), Staph. warneri (1) \\
\hline & & $m s r$ & 6 & 22.2 & Staph. xylosus (3), Staph. epidermidis (2), Staph. hominis (1) \\
\hline & & Unknown & 8 & 29.6 & $\begin{array}{l}\text { Staph. equorum (3), Staph. xylosus (1), Staph. cohnii (1), Staph. fleurettii (1), Staph. } \\
\text { spp. (2) }\end{array}$ \\
\hline \multirow[t]{4}{*}{ Clindamycin } & \multirow[t]{4}{*}{3.4} & $\operatorname{erm}(\mathrm{B})$ & 2 & 14.3 & Staph. chromogenes (1), Staph. sciuri (1) \\
\hline & & $\operatorname{erm}(\mathrm{C})$ & 8 & 57.2 & Staph. haemolyticus (4), Staph. epidermidis (4) \\
\hline & & $\ln u(\mathrm{~A})$ & 1 & 7.1 & Staph. xylosus (1) \\
\hline & & Unknown & 3 & 21.4 & Staph. xylosus (1), Staph. fleurettii (1), Staph. lentus (1) \\
\hline \multirow[t]{3}{*}{ Chloramphenicol } & \multirow[t]{3}{*}{3.1} & $\operatorname{cat}_{p C 221}$ & 7 & 53.8 & Staph. epidermidis (3), Staph. xylosus (2), Staph. chromogenes (1), Staph. sciuri (1) \\
\hline & & cat $_{p C 223}$ & 4 & 30.8 & Staph. cohnii (1), Staph. haemolyticus (1), Staph. simulans (1), Staph. xylosus (1) \\
\hline & & Unknown & 2 & 15.4 & Staph. haemolyticus (1), Staph. simulans (1) \\
\hline \multirow{2}{*}{ Kanamycin } & \multirow[t]{2}{*}{2.4} & $a a c\left(6^{\prime}\right)-I e-a p h\left(2^{\prime}\right)-I a$ & 7 & 70.0 & Staph. epidermidis (4), Staph. sciuri (1), Staph. chromogenes (1), Staph. fleurettii (1) \\
\hline & & $\operatorname{aph}\left(3^{\prime}\right)-I I I$ & 3 & 30.0 & Staph. haemolyticus (2), Staph. epidermidis (1) \\
\hline \multirow[t]{2}{*}{ Gentamicin } & \multirow[t]{2}{*}{2.4} & $\operatorname{aac}\left(6^{\prime}\right)-I e-a p h\left(2^{\prime}\right)-I a$ & 7 & 70.0 & Staph. epidermidis (4), Staph. sciuri (1), Staph. chromogenes (1), Staph. fleurettii (1) \\
\hline & & Unknown & 3 & 30.0 & Staph. haemolyticus (2), Staph. xylosus (1) \\
\hline \multirow[t]{4}{*}{ Trimethoprim } & \multirow[t]{4}{*}{1.2} & $d f r(\mathrm{~A})$ & 1 & 20.0 & Staph. epidermidis (1) \\
\hline & & $d f r(\mathrm{D})$ & 2 & 40.0 & Staph. sciuri (1), Staph. fleurettii (1) \\
\hline & & $d f r(\mathrm{G})$ & 1 & 20.0 & Staph. vitulinus (1) \\
\hline & & $d f r(\mathrm{~K})$ & 1 & 20.0 & Staph. chromogenes (1) \\
\hline
\end{tabular}

${ }^{1}$ Antimicrobial resistance genes and their functions: $m e c A$ and $m e c A 1=$ penicillin-binding proteins; blaZ $=\beta$-lactamase; tet $(\mathrm{K})$ and $\operatorname{tet}(\mathrm{L})=$ tetracycline efflux proteins; $\operatorname{str}=$ streptomycin nucleotidyltransferase; ant (6)-Ia = streptomycin adenyltransferase; $\operatorname{erm}(\mathrm{B})$ and $\operatorname{erm}(\mathrm{C})=$ macrolide, lincosamide, and streptogramin $\mathrm{B} 23 \mathrm{~S}$ rRNA methylase; $m s r=$ macrolide efflux gene; $\ln u(\mathrm{~A})=$ lincosamide nucleotidyltransferase; $c_{t} t_{p C 21}$ and $c a t_{p C 223}=$ chloramphenicol acetyltransferases; $a a c\left(6^{\prime}\right)-I e-a p h\left(2^{\prime}\right)-I a=$ gentamicin, kanamycin, and neomycin acetyltransferase; $\operatorname{aph}\left(3^{\prime}\right)-I I I=$ kanamycin and neomycin phosphotransferase; $d f r(\mathrm{~A}), d f r(\mathrm{D}), d f r(\mathrm{G}), d f r(\mathrm{~K})=\operatorname{trimethoprim-resistant}$ dihydrofolate reductases.

z ${ }^{2}$ Oxacillin, indicator antimicrobial for the presence of an alternative penicillin-binding protein (PBP 2a) encoded by mec genes.

${ }^{3}$ Penicillin used for the prediction of a $\beta$-lactamase.

$\approx \quad{ }^{4}$ Does not produce $\beta$-lactamase, but contained $m e c A$. 
Table 6. Occurrence of multiple antimicrobial resistance genes in CNS isolated from the milk of 20 different cows suffering from bovine mastitis

\begin{tabular}{|c|c|c|c|}
\hline Isolate & CNS species & Mastitis & Resistance $^{1,2}$ \\
\hline \multicolumn{4}{|l|}{$m e c A$ positive } \\
\hline M1529/10 & Staph. epidermidis & Subclinical & erm(C): CLI, ERY; tet(K): TET; str: STR; blaZ: PEN; aac(6')-Ie-aph(2')-Ia: GEN-KAN; $d f r(\mathrm{~A})$ : TMP; mecA: OXA \\
\hline M1186/10 & Staph. epidermidis & Clinical & erm(C): CLI, ERY; tet(K): TET; ant(6)-Ia: STR; blaZ: PEN; aac(6')-Ie-aph(2')-Ia: GEN-KAN; mecA: OXA \\
\hline M4460/09 & Staph. fleurettii & Clinical & erm(B): CLI, ERY; str: STR; blaZ: PEN; aac(6')-Ie-aph(2')-Ia: GEN-KAN; $d f r(\mathrm{D})$ : TMP; mecA: OXA \\
\hline M1570/10 & Staph. haemolyticus & Clinical & erm $(\mathrm{C})$ : CLI, ERY; tet(K): TET; blaZ: PEN; aph(3')-III: KAN; mecA: OXA \\
\hline M744/10 & Staph. epidermidis & Subclinical & str: STR; $\operatorname{cat}_{n}$ : CHL; aac (6')-Ie-aph(2')-Ia: GEN-KAN; $\operatorname{erm}(\mathrm{C})$ : CLI. ERY; mecA: OXA \\
\hline M1383/10 & Staph. epidermidis & Subclinical & $\operatorname{erm}(\mathrm{C})$ : CLI, ERY; blaZ: PEN; aac(6')-Ie-aph(2')-Ia: GEN-KAN; mecA: OXA \\
\hline M1965/10 & Staph. sciuri & Clinical & tet(K): TET; str: STR; aac(6')-Ie-aph(2')-Ia: GEN-KAN; $d f r(\mathrm{D})$ : TMP; mecA1: OXA \\
\hline $\mathrm{M} 8 / 10$ & Staph. epidermidis & Clinical & ant(6)-Ia: STR; blaZ: PEN; cat ${ }_{p C 221}$ : CHL; $\operatorname{aph}\left(3^{\prime}\right)$-III: KAN; erm(C): CLI, ERY; mecA: OXA \\
\hline M1201/10 & Staph. sciuri & Subclinical & $\operatorname{tet}(\mathrm{K}): \mathrm{TET} ;$ str: STR; cat ${ }_{p C 221}:$ CHL; mecA1: OXA \\
\hline M703/10 & Staph. epidermidis & Subclinical & blaZ: PEN; msr: ERY; mecA: OXA \\
\hline M3901/09 & Staph. sciuri & Clinical & tet(K): TET; str: STR; mecA1: OXA \\
\hline M425/10 & Staph. chromogenes & Subclinical & $\operatorname{erm}(\mathrm{B}): \mathrm{CLI}, \mathrm{ERY} ; \operatorname{tet}(\mathrm{L}): \mathrm{TET} ;$ blaZ: PEN; $c t_{p C 221}$ : CHL; $d f r(\mathrm{~K}):$ TMP \\
\hline M47/10 & Staph. chromogenes & Subclinical & tet (L): TET: str: STR: blaZ: PEN; aac(6')-Ie-aph(2')-Ia: GEN-KAN \\
\hline M1256/10 & Staph. warneri & Subclinical & str: STR; blaZ: PEN; erm(C): CLI, ERY \\
\hline M4233-1/09 & Staph. epidermidis & Subclinical & $\operatorname{erm}(\mathrm{C})$ : CLI-ERY; tet $(\mathrm{K})$ : TET; str: STR \\
\hline M4298-1/09 & Staph. epidermidis & Subclinical & tet(K): TET; str: STR; blaZ: PEN; cat ${ }_{p C 221}$ : CHL \\
\hline M46/10 & Staph. chromogenes & Subclinical & tet $(\mathrm{K})$ : TET; str: STR; blaZ: PEN \\
\hline M523/10 & Staph. epidermidis & Clinical & tet $(\mathrm{K})$ : TET; str: STR; blaZ: PEN \\
\hline $\mathrm{M} 619-2 / 10$ & Staph. haemolyticus & Subclinical & ant(6)-Ia: STR; blaZ: PEN; aph(3')-III: KAN \\
\hline M1094-1/10 & Staph. warneri & Subclinical & tet(K): TET; str: STR; blaZ, PEN \\
\hline
\end{tabular}

${ }^{1}$ Antimicrobial resistance genes and their functions: $\operatorname{erm}(\mathrm{B})$ and $\operatorname{erm}(\mathrm{C})=$ macrolide, lincosamide, and streptogramin B $23 \mathrm{~S}$ rRNA methylase; tet $(\mathrm{K})$ and $\operatorname{tet}(\mathrm{L})=$ tetracycline efflux proteins; str = streptomycin nucleotidyltransferase; blaZ = $\beta$-lactamase; $a a c\left(6^{\prime}\right)-I e-a p h\left(2^{\prime}\right)-I a=$ gentamicin, kanamycin, and neomycin acetyltransferase; $d f r(\mathrm{~A}), d f r(\mathrm{D})$, $d f r(\mathrm{G}), d f r(\mathrm{~K})=$ trimethoprim-resistant dihydrofolate reductases; mecA and mecA 1 = penicillin-binding proteins; ant $(6)-I a=$ streptomycin adenyltransferase; $a p h\left(3^{\prime}\right)-I I I=$ kanamycin and neomycin phosphotransferase; cat $_{p C 221}$ and cat $_{p C 223}=$ chloramphenicol acetyltransferases; $m s r=$ macrolide efflux gene.

${ }^{2}$ Antibiotics: $\mathrm{CLI}=$ clindamycin; $\mathrm{TET}=$ tetracycline; $\mathrm{STR}=$ streptomycin; $\mathrm{PEN}=$ penicillin; $\mathrm{KAN}=$ kanamycin; $\mathrm{GEN}=$ gentamicin; $\mathrm{TMP}=$ trimethoprim; $\mathrm{ERY}=$ erythromycin; $\mathrm{OXA}=$ oxacillin; $\mathrm{CHL}=$ chloramphenicol 


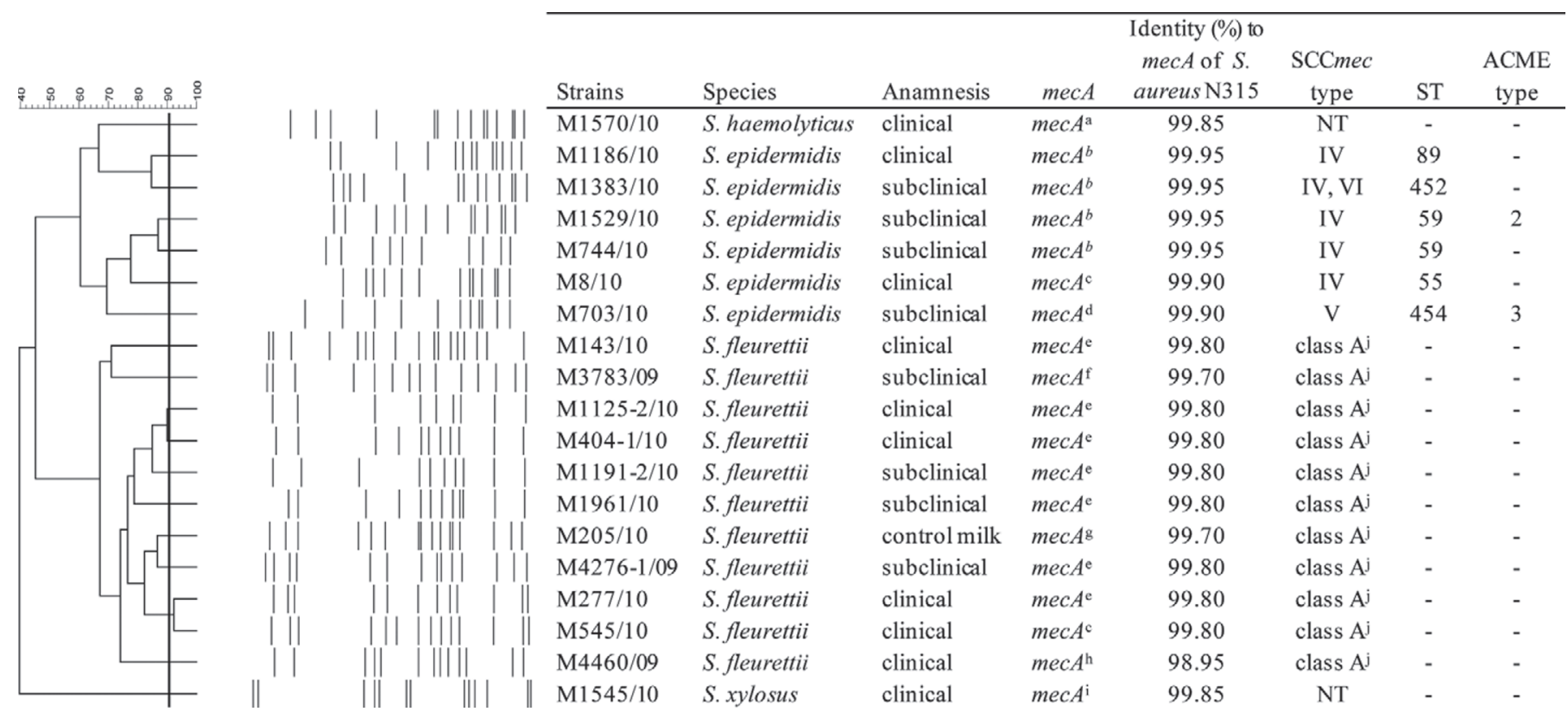

Figure 1. Genetic background and properties of methicillin-resistant CNS from bovine mastitis milk from Switzerland. The phylogenetic tree was constructed from pulsed-field gel electrophoresis (PFGE) patterns of 19 methicillin-resistant CNS isolates. Cluster analysis was generated by Bionumerics 6.6 (Applied Maths, Kortijk, Belgium). The dotted line indicates the cut-off value of $\geq 90 \%$ determining clonality between the isolates, according to the criteria of Tenover et al. (1995). (a) mecA of Staphylococcus haemolyticus M1570/10 (EMBL accession no. HE978799); (b) mecA identical to mecA of Staphylococcus epidermidis RP26A (EMBL accession no. CP000029); (c) mecA of Staph. epidermidis M8/10 (EMBL accession no. HE978797); (d) mecA of Staph. epidermidis M703/10 (EMBL accession no. HE978798); (e) mecA identical to mecA of Staphylococcus fleurettii M143/10 (EMBL accession no. HE978795); (f) mecA of Staph. fleurettii M3783/09 (EMBL accession no. HE978796); (g) mecA of Staph. fleurettii M205/10 (EMBL accession no. HE978794); (h) mecA of Staph. fleurettii M4460/09 (EMBL accession no. HE861945); (i) mecA of Staphylococcus xylosus M1545/10 (EMBL accession no. HE978800); (j) mecA of Staph. fleurettii has been reported to be chromosomally encoded and only contains part of the class A mec gene complex; it is not associated with a staphylococcal cassette chromosome (SCCmec) element (Tsubakishita et al., 2010). NT = not typeable.

detected in 4 MSSE ST111 and in 1 MSSE ST456. None of the Staph. epidermidis isolates carried the biofilm-formation operon ica (Figure 1).

\section{DISCUSSION}

Many diverse CNS species have been identified in bovine milk, and MALDI-TOF MS is a reliable and rapid method to identify CNS species (Loonen et al., 2012). We observed that a short ethanol-formic acid extraction is necessary for accurate identification. The CNS in milk were frequently detected as single bacterial species, suggesting that these species were the infectious agents. However, the presence of these CNS species was not correlated with a clinical mastitis diagnosis (Table 3). The most frequently occurring species in this study were Staph.xylosus, Staph. chromogenes, Staph. sciuri, and Staph. haemolyticus, as reported in other studies (Piessens et al., 2011; Supré et al., 2011; Waller et al., 2011). Although Staph. xylosus is not known to cause mastitis, it was detected in $35.9 \%$ of the milk samples in our study and as a single species in $22.8 \%$ of those samples, emphasizing previous conclusions that Staph. xylosus is an underestimated pathogenic CNS in bovine mastitis (Supré et al., 2011). Additionally, two-thirds of the Staph. xylosus isolates were resistant to oxacillin but lacked a known mec gene. The absence of a mecA gene was also observed in other oxacillin-resistant CNS isolates (Table 5). The presence of a bla $Z$ overexpressing $\beta$-lactamase may explain decreased susceptibility to oxacillin in some of the strains, as has been described in borderline oxacillin-resistant Staph. aureus (McDougal and Thornsberry, 1986). For the other oxacillin-resistant isolates lacking mec and blaZ genes, independent mechanisms (which may not be related to an acquired resistance gene) explain the decreased susceptibility to oxacillin with MIC in the range of 0.5 to $2.0 \mu \mathrm{g} / \mathrm{mL}$. Oxacillin resistance in Staph. sciuri may also depend on $m e c A 1$ gene overexpression. Alterations to the promoter region of mecA1 are necessary for high-level mecA1 expression and oxacillin resistance in Staph. sciuri (Wu et al., 2001, 2005; Couto et al., 2003). In our study, none of the Staph. sciuri strains contained the -10 promoter mutation that is associated with oxacillin resistance (Wu et al., 2001). However, the MIC for these isolates were between 0.5 and $1.0 \mu \mathrm{g} / \mathrm{mL}$, values that are above 
the CLSI and EUCAST resistance breakpoints. The clinical and therapeutic relevance of decreased susceptibility to oxacillin remains to be clarified. The oxacillin breakpoint may be set low to properly gauge resistance in CNS from bovine mastitis cases (Fessler et al., 2010), and detection of acquired mec genes may be necessary for correct interpretation of the antibiogram.

The mecA gene was detected in Staph. epidermidis, Staph. fleurettii, Staph. haemolyticus, and Staph. xylosus. Three mecA genes that differed from each other in only a few base pairs were found in the methicillin-resistant Staph. fleurettii and Staph. epidermidis isolates, suggesting the independent acquisition of the mecA gene in these species. This conclusion is supported by the observation that the different SCCmec elements were detected in individual Staph. epidermidis isolates, and that all but one Staph. fleurettii isolate contained a $m e c A$ gene associated with the class A mec gene complex. It has been reported that the mecA-containing region in Staph. fleurettii is not associated with a SCCmec element but is encoded chromosomally within a part of the class A mec gene complex (Tsubakishita et al., 2010). It is therefore expected that the Kondo typing method (Kondo et al., 2007) detects the chromosomal class A mec gene complex in Staph. fleurettii. Genetic diversity was confirmed by PFGE, which showed that, except for 2 pairs of Staph. fleurettii with similar PFGE profiles, all methicillin-resistant CNS isolates had different PFGE profiles. Despite different PFGE profiles, Staph. epidermidis isolates belonging to the ST111 and ST59 groups were predominant in bovine mastitis cases, suggesting that a specific clonal lineage of Staph. epidermidis has adapted to the udder environment (Piessens et al., 2012). Half of the Staph. epidermidis isolates contained an ACME operon, which may be involved in host adaptation in humans (Miragaia et al., 2009). The ACME were mainly observed in the Staph. epidermidis ST59 or ST111 groups, suggesting that it may also play a role in host adaptation in cows. Additionally, Staph. epidermidis was the predominant CNS species among those that contained multiple antimicrobial resistance genes. Multiple resistance genes were also found in Staph. sciuri, Staph. chromogenes, Staph. haemolyticus, and Staph. fleurettii, and these genes were frequently associated with the presence of the mecA gene. Genes conferring resistance to clinically relevant antimicrobials such as the penicillins, macrolides, lincosamides, and aminoglycosides were also detected. In total, $15.1 \%$ of the isolates studied were resistant to more than 2 antimicrobials, and some strains were virtually resistant to all antimicrobials authorized for the treatment of mastitis. The remaining CNS isolates were susceptible to antimicrobials commonly used in mastitis treatment.
Our study demonstrated that CNS species in milk from cows experiencing mastitis are generally susceptible to the antimicrobials commonly used for treatment. However, CNS have the potential to acquire resistance genes, leading to therapeutic failures. Some multidrugresistant isolates, especially Staph. epidermidis, Staph. chromogenes, and Staph. haemolyticus, are present in bovine mastitis milk and may resist antimicrobial treatment. An antibiogram is therefore recommended for targeted therapy, and chronically infected cows should be culled from the herd.

\section{ACKNOWLEDGMENTS}

This study was supported by Grant No.1.11.21 to V. P. from the Swiss Federal Veterinary Office (BVET); J. P. R. received a scholarship from the Federal Commission for Scholarships for Foreign Students. We thank Alexandra Collaud, Alexandra Rossano, Juliette Wipf, Stefanie Ackermann, and Susanne Rickli from the Institute of Veterinary Bacteriology (University of Bern, Switzerland) for technical assistance. We also thank Michèle Bodmer from the Clinic for Ruminants (University of Bern, Switzerland) and Marcus Doherr and Martin Reist from the Veterinary Public Health Institute (University of Bern, Switzerland) for advice.

\section{REFERENCES}

Barbier, F., E. Ruppe, D. Hernandez, D. Lebeaux, P. Francois, B. Felix, A. Desprez, A. Maiga, P. L. Woerther, K. Gaillard, C. Jeanrot, M. Wolff, J. Schrenzel, A. Andremont, and R. Ruimy. 2010. Methicillin-resistant coagulase-negative staphylococci in the community: high homology of SCCmec IVa between Staphylococcus epidermidis and major clones of methicillin-resistant Staphylococcus aureus. J. Infect. Dis. 202:270-281.

Büttner, S., O. Flechtner, C. Müntener, and G. Overesch. 2011. Bericht über den Vertrieb von Antibiotika in der Veterinärmedizin und das Antibiotikaresistenzmonitoring bei Nutztieren in der Schweiz (ARCH-VET 2010). Federal Veterinary Office and Swissmedic, Bern, Switzerland. www.swissmedic.ch/archvet-d.asp.

Clinical and Laboratory Standards Institute. 2009. Methods for Dilution Antimicrobial Susceptibility Tests for Bacteria that Grow Aerobically. Vol. 29, no. 2. 8th ed. Approved standard M07-A8. Clinical and Laboratory Standards Institute, Wayne, PA.

Couto, I., H. de Lencastre, E. Severina, W. Kloos, J. A. Webster, R. J. Hubner, I. S. Sanches, and A. Tomasz. 1996. Ubiquitous presence of a mecA homologue in natural isolates of Staphylococcus sciuri. Microb. Drug Resist. 2:377-391.

Couto, I., I. S. Sanches, R. Sá-Leão, and H. de Lencastre. 2000. Molecular characterization of Staphylococcus sciuri strains isolated from humans. J. Clin. Microbiol. 38:1136-1143.

Couto, I., S. W. Wu, A. Tomasz, and H. de Lencastre. 2003. Development of methicillin resistance in clinical isolates of Staphylococcus sciuri by transcriptional activation of the mecA homologue native to the species. J. Bacteriol. 185:645-653.

De Vliegher, S., L. K. Fox, S. Piepers, S. McDougall, and H. W. Barkema. 2012. Invited review: Mastitis in dairy heifers: Nature of the disease, potential impact, prevention, and control. J. Dairy Sci. 95:1025-1040.

Diep, B. A., S. R. Gill, R. F. Chang, T. H. Phan, J. H. Chen, M. G. Davidson, F. Lin, J. Lin, H. A. Carleton, E. F. Mongodin, G. F. 
Sensabaugh, and F. Perdreau-Remington. 2006. Complete genome sequence of USA300, an epidemic clone of community-acquired methicillin-resistant Staphylococcus aureus. Lancet 367:731-739.

Diep, B. A., G. G. Stone, L. Basuino, C. J. Graber, A. Miller, S. A. des Etages, A. Jones, A. M. Palazzolo-Ballance, F. PerdreauRemington, G. F. Sensabaugh, F. R. Deleo, and H. F. Chambers. 2008. The arginine catabolic mobile element and staphylococcal chromosomal cassette mec linkage: Convergence of virulence and resistance in the USA300 clone of methicillin-resistant Staphylococcus aureus. J. Infect. Dis. 197:1523-1530.

Farrell, D. J., M. Castanheira, and I. Chopra. 2011. Characterization of global patterns and the genetics of fusidic acid resistance. Clin. Infect. Dis. 52(Suppl. 7):S487-492.

Fessler, A. T., C. Billerbeck, K. Kadlec, and S. Schwarz. 2010. Identification and characterization of methicillin-resistant coagulasenegative staphylococci from bovine mastitis. J. Antimicrob. Chemother. 65:1576-1582.

García-Álvarez, L., M. T. Holden, H. Lindsay, C. R. Webb, D. F. Brown, M. D. Curran, E. Walpole, K. Brooks, D. J. Pickard, C. Teale, J. Parkhill, S. D. Bentley, G. F. Edwards, E. K. Girvan, A. M. Kearns, B. Pichon, R. L. Hill, A. R. Larsen, R. L. Skov, S. J. Peacock, D. J. Maskell, and M. A. Holmes. 2011. Methicillinresistant Staphylococcus aureus with a novel mecA homologue in human and bovine populations in the UK and Denmark: A descriptive study. Lancet Infect. Dis. 11:595-603.

Goering, R. V., L. K. McDougal, G. E. Fosheim, K. K. Bonnstetter, D. J. Wolter, and F. C. Tenover. 2007. Epidemiologic distribution of the arginine catabolic mobile element among selected methicillin-resistant and methicillin-susceptible Staphylococcus aureus isolates. J. Clin. Microbiol. 45:1981-1984.

Gu, J., H. Li, M. Li, C. Vuong, M. Otto, Y. Wen, and Q. Gao. 2005. Bacterial insertion sequence IS256 as a potential molecular marker to discriminate invasive strains from commensal strains of Staphylococcus epidermidis. J. Hosp. Infect. 61:342-348.

Ito, T., K. Hiramatsu, A. Tomasz, H. de Lencastre, V. Perreten, M. T. Holden, D. C. Coleman, R. Goering, P. M. Giffard, R. L. Skov, K. Zhang, H. Westh, F. O'Brien, F. C. Tenover, D. C. Oliveira, S. Boyle-Vavra, F. Laurent, A. M. Kearns, B. Kreiswirth, K. S. Ko, H. Grundmann, J. E. Sollid, J. F. John Jr., R. Daum, B. Soderquist, and G. Buist. 2012. Guidelines for reporting novel mecA gene homologues. Antimicrob. Agents Chemother. 56:4997-4999.

Kondo, Y., T. Ito, X. X. Ma, S. Watanabe, B. N. Kreiswirth, J. Etienne, and K. Hiramatsu. 2007. Combination of multiplex PCRs for staphylococcal cassette chromosome mec type assignment: Rapid identification system for mec, $c c r$, and major differences in junkyard regions. Antimicrob. Agents Chemother. 51:264-274.

Kuhnert, P., S. Capaul, J. Nicolet, and J. Frey. 1996. Phylogenetic positions of Clostridium chauvoei and Clostridium septicum based on 16S rRNA gene sequences. Int. J. Syst. Bacteriol. 46:1174-1176.

Loonen, A. J., A. R. Jansz, J. N. Bergland, M. Valkenburg, P. F. Wolffs, and A. J. van den Brule. 2012. Comparative study using phenotypic, genotypic, and proteomics methods for identification of coagulase-negative staphylococci. J. Clin. Microbiol. 50:14371439.

Lüthje, P., and S. Schwarz. 2006. Antimicrobial resistance of coagulase-negative staphylococci from bovine subclinical mastitis with particular reference to macrolide-lincosamide resistance phenotypes and genotypes. J. Antimicrob. Chemother. 57:966-969.

McDougal, L. K., and C. Thornsberry. 1986. The role of $\beta$-lactamase in staphylococcal resistance to penicillinase-resistant penicillins and cephalosporins. J. Clin. Microbiol. 23:832-839.

Miragaia, M., H. de Lencastre, F. Perdreau-Remington, H. F. Chambers, J. Higashi, P. M. Sullam, J. Lin, K. I. Wong, K. A. King, M. Otto, G. F. Sensabaugh, and B. A. Diep. 2009. Genetic diversity of arginine catabolic mobile element in Staphylococcus epidermidis. PLoS ONE 4:e7722.

Perreten, V., L. Vorlet-Fawer, P. Slickers, R. Ehricht, P. Kuhnert, and J. Frey. 2005. Microarray-based detection of 90 antibiotic resistance genes of gram-positive bacteria. J. Clin. Microbiol. 43:2291-2302.
Piessens, V., S. De Vliegher, B. Verbist, G. Braem, A. Van Nuffel, L. De Vuyst, M. Heyndrickx, and E. Van Coillie. 2012. Intra-species diversity and epidemiology varies among coagulase-negative Staphylococcus species causing bovine intramammary infections. Vet. Microbiol. 155:62-71.

Piessens, V., E. Van Coillie, B. Verbist, K. Supré, G. Braem, A. Van Nuffel, L. De Vuyst, M. Heyndrickx, and S. De Vliegher. 2011. Distribution of coagulase-negative Staphylococcus species from milk and environment of dairy cows differs between herds. J. Dairy Sci. 94:2933-2944.

Pyörälä, S., and S. Taponen. 2009. Coagulase-negative staphylococciEmerging mastitis pathogens. Vet. Microbiol. 134:3-8.

Rajala-Schultz, P. J., A. H. Torres, F. J. Degraves, W. A. Gebreyes, and P. Patchanee. 2009. Antimicrobial resistance and genotypic characterization of coagulase-negative staphylococci over the dry period. Vet. Microbiol. 134:55-64.

Sampimon, O. C., T. J. Lam, D. J. Mevius, Y. H. Schukken, and R. N. Zadoks. 2011. Antimicrobial susceptibility of coagulase-negative staphylococci isolated from bovine milk samples. Vet. Microbiol. 150:173-179.

Sawant, A. A., B. E. Gillespie, and S. P. Oliver. 2009. Antimicrobial susceptibility of coagulase-negative Staphylococcus species isolated from bovine milk. Vet. Microbiol. 134:73-81.

Schnellmann, C., V. Gerber, A. Rossano, V. Jaquier, Y. Panchaud, M. G. Doherr, A. Thomann, R. Straub, and V. Perreten. 2006. Presence of new mecA and $m p h(\mathrm{C})$ variants conferring antibiotic resistance in Staphylococcus spp. isolated from the skin of horses before and after clinic admission. J. Clin. Microbiol. 44:4444-4454.

Supré, K., F. Haesebrouck, R. N. Zadoks, M. Vaneechoutte, S. Piepers, and S. De Vliegher. 2011. Some coagulase-negative Staphylococcus species affect udder health more than others. J. Dairy Sci. 94:2329-2340.

Tenover, F. C., R. D. Arbeit, R. V. Goering, P. A. Mickelsen, B. E. Murray, D. H. Persing, and B. Swaminathan. 1995. Interpreting chromosomal DNA restriction patterns produced by pulsed-field gel electrophoresis: Criteria for bacterial strain typing. J. Clin. Microbiol. 33:2233-2239.

Thomas, J. C., M. R. Vargas, M. Miragaia, S. J. Peacock, G. L. Archer, and M. C. Enright. 2007. Improved multilocus sequence typing scheme for Staphylococcus epidermidis. J. Clin. Microbiol. 45:616-619.

Tsubakishita, S., K. Kuwahara-Arai, T. Sasaki, and K. Hiramatsu. 2010. Origin and molecular evolution of the determinant of methicillin resistance in staphylococci. Antimicrob. Agents Chemother. 54:4352-4359.

Waller, K. P., A. Aspan, A. Nyman, Y. Persson, and U. G. Andersson. 2011. CNS species and antimicrobial resistance in clinical and subclinical bovine mastitis. Vet. Microbiol. 152:112-116.

Walther, C., and V. Perreten. 2007. Letter to the editor: Methicillinresistant Staphylococcus epidermidis in organic milk production. J. Dairy Sci. 90:5351.

Wielders, C. L., M. R. Vriens, S. Brisse, L. A. Graaf-Miltenburg, A. Troelstra, A. Fleer, F. J. Schmitz, J. Verhoef, and A. C. Fluit. 2001. In vivo transfer of mecA DNA to Staphylococcus aureus. Lancet 357:1674-1675.

Woodford, N. 2005. Biological counterstrike: Antibiotic resistance mechanisms of Gram-positive cocci. Clin. Microbiol. Infect. 11:221.

Wu, S., H. de Lencastre, and A. Tomasz. 1998. Genetic organization of the mecA region in methicillin-susceptible and methicillin-resistant strains of Staphylococcus sciuri. J. Bacteriol. 180:236-242.

Wu, S. W., H. de Lencastre, and A. Tomasz. 2001. Recruitment of the mecA gene homologue of Staphylococcus sciuri into a resistance determinant and expression of the resistant phenotype in Staphylococcus aureus. J. Bacteriol. 183:2417-2424.

Wu, S. W., H. D. Lencastre, and A. Tomasz. 2005. Expression of high-level methicillin resistance in Staphylococcus aureus from the Staphylococcus sciuri mecA homologue: Role of mutation(s) in the genetic background and in the coding region of mecA. Microb. Drug Resist. 11:215-224. 